\title{
Hyper-compressions: The rise of flash fiction in "post-transitional" South Africa
}

\section{Peter Blair}

University of Chester

[Final typescript (or 'post-print') version of article accepted for publication in The Journal of Commonwealth Literature (special issue 'The South African Short Story in the Post-2000s').]

\begin{abstract}
This article begins with a survey of flash fiction in "post-transitional" South Africa, which it relates to the nation's post-apartheid canon of short stories and short-short stories, to the international rise of flash fiction and "sudden fiction", and to the historical particularities of South Africa's "post-transition". It then undertakes close readings of three flash fictions republished in the article, each less than 450 words: Tony Eprile's "The interpreter for the tribunal" (2007), which evokes the psychological and ethical complexities, and long-term ramifications, of the Truth and Reconciliation Commission; Michael Cawood Green's "Music for a new society" (2008), a carjacking story that invokes discourses about violent crime and the "“new' South Africa"; and Stacy Hardy's "Kisula" (2015), which maps the psychogeography of cross-racial sex and transnational identity-formation in an evolving urban environment. The article argues that these exemplary flashes are "hypercompressions", in that they compress and develop complex themes with a long literary history and a wide contemporary currency. It therefore contends that flash fiction of South Africa's post-transition should be recognized as having literary-historical significance, not just as an inherently metonymic form that reflects, and alludes to, a broader literary culture, but as a genre in its own right.
\end{abstract}

\section{Keywords}

flash fiction, Michael Cawood Green, post-apartheid, post-transition, short-short story, short story, South Africa, Stacy Hardy, sudden fiction, Tony Eprile

As two recent anthologies demonstrate, flash fiction has deep historical roots and flourishes in many countries. Short: An International Anthology of Five Centuries of Short-Short Stories, Prose Poems, Brief Essays, and Other Short Prose Forms (Ziegler, 2014) includes writers from 38 countries. Flash Fiction International (Merrill et al., 2015), which favours recent decades but goes back to Ancient Rome, features 50. The English-language flash 
thrived in the USA, under the umbrella-term "short-short story", from the 1920s, waned in the 1950s, but enjoyed a resurgence from the mid-1970s (Casto, 2008; Masih, 2009). In 1986 the first of five "sudden fiction" anthologies, edited by Robert Shapard and James Thomas, was published, defining "sudden" as 1500 or 2000 words maximum (1986, 1989, 1996, 2007; Shapard et al., 2010). The term "flash fiction" was subsequently popularized by an eponymous anthology, which set a limit of 750 words (J. Thomas et al., 1992). While flash now encompasses a wide variety of inventively named subgenres, often with lower arbitrary word-limits or gimmicky fixed-lengths, there are critical consensuses about quantitative and qualitative definition: "flash" fictions are stories of up to 750 (or at most 1000) words; good flashes are generally feats of "compression", often entailing subtle intertextual allusion, that stimulate an implied reader to fill narrative "gaps"; and they tend, as a consequence, to be particularly rich (relative to longer stories) in "implication" or inference (Blair, 2013; Chantler, 2008; Holdefer, 2014; Nelles, 2012; B. Thomas, 2014; Trimarco and Hurley, 2008; T. Williams, 2014).

Flash fiction is nevertheless scarce in the numerous anthologies of South African "short" stories, including the most comprehensively diachronic. The Best of South African Short Stories (Turner, 1991), a Reader's Digest compendium for the nascent post-apartheid nation, boasted "over seventy illustrated stories of our land and its people" (3) from the 1880s to the 1980s by "over sixty authors" (5); yet only three pieces might, at a push, pass as flashes: "The Cannibal's Bird" (1938), a "traditional Nguni story transcribed by Frank Brownlee" in about 750 words (89); and RRR Dhlomo's “The Death of Masaba" (1929) and Mothobi Mutloatse's "Honest Gladys" (1982), each around 900 words. Flashes are similarly rare in Michael Chapman's Omnibus of A Century of South African Short Stories (2007), which collates Jean Marquard's A Century of South African Short Stories (1978), Martin Trump's revised edition (1993), and his own The New Century of South African Short Stories (2004). In his Introduction to The New Century, Chapman asks "How long or short may a story be?" (2004: xiii); but of the Omnibus's 121 stories, only a few pre-twentieth-century translations (from San, isiZulu, and Dutch/Afrikaans), Brownlee's "transcription" (which Chapman also includes), and Liz Gunner's “The Mandela Days" (1992) might qualify as flashes, while the Dhlomo story again represents the 750-1000-word grey area. Amongst the next-shortest are two from Maureen Isaacson's Holding Back Midnight (1992), which Zoë Wicomb praised for its stories' "racy super-shortness" (2001: 163); but these are merely "sudden". That these anthologies' shortest pieces are folktales is at least germane, given that flash has antecedents, perhaps roots, in oral tradition. More recently, the publisher's blurb for 
Twenty in 20: The Best Short Stories of South Africa's Twenty Years of Democracy (Langa et al., 2014), which it promotes as "a longstanding reference for South African literary posterity", hails Chris van Wyk's "Relatives" (1995) as a "miniature masterpiece"; but this is towards the upper limit for a "sudden", a category into which the anthology's shortest piece, Wamuwi Mbao's “The Bath” (2013; around 1250 words), more comfortably fits. Only a story inset within Van Wyk's "miniature" might be considered a flash. Nor is flash fiction discussed in the major post-apartheid literary histories (Attwell and Attridge, 2012; Chapman, 2003/1996; Cornwell et al., 2010; Van Wyk Smith, 1990). The South African flash has not been regarded as a serious form; but it is also the case that most of these landmark anthologies and histories were compiled too early to catch its remarkable burgeoning from the mid-2000s.

Anthologies at least reflect a longstanding tendency towards brevity, with South African stories often falling within the "sudden" limit. This is particularly true of those written for periodicals, epitomized by Herman Charles Bosman's 60 Oom Schalk Lourens tales (1930-51) and 80 "Voorkamer" conversation pieces (1950-51) (Bosman, 2007; 2011); and over 90 stories by black writers, mostly South Africans, published (1951-58) in Drum (Chapman, 1989). Some Drum stories, such as Casey Motsisi's anti-apartheid anthropomorphisms “Johburg Jailbugs" (1957) and "If Bugs Were Men" (1958) (in Chapman, 1989: 171-4), are well within the "flash" limit. Nadine Gordimer features in Sudden Fiction International (1989), which also includes South African emigrants Bessie Head, Denis Hirson, and Barry Yourgrau, and in New Sudden Fiction (2007) and Crafting the Very Short Story (Mills, 2003). South Africans appear, too, in overseas flash anthologies. Yourgrau, a US-naturalized writer of often-surreal flashes, is the sole representative in Ziegler's Short, but appears with Damon Galgut (whose novel The Quarry (1995/2004) has many flash-like chapters) in Peter Wild's The Flash (2007). Wild also includes Patrick Neate's 100-word “Jo'burg" (25), which skewers white racism and post-apartheid political correctness, as well as the needy posturing of visiting liberals. In Flash Fiction International, South Africa is represented by emigrant Tony Eprile and immigrant Karina M. Szczurek. Flash: The International Short-Short Story Magazine, edited by Peter Blair and Ashley Chantler in the UK, has since its foundation in 2008 published 44 flashes by 17 South Africans, including Elleke Boehmer, Michael Cawood Green, Allan Kolski Horwitz, Liesl Jobson, Shubnum Khan, Kobus Moolman, Sally-Ann Murray, Kelwyn Sole, and Szczurek. Within South Africa, three anthologies wholly or partly devoted to local flash have appeared, the first two arising from women's writing workshops: Women Flashing (Fisher, 
2005), which includes 55-word stories (known as "55 fiction"); Writing the Self (Schuster et al., 2008), which includes 100-word stories (known as “drabbles”); and My Holiday Shorts (Mabaso, 2013). Fiction of flash-length regularly appears in domestic literary magazines like New Contrast, and at least two stories have appeared under the heading "Flash Fiction" in English Academy Review, the peer-reviewed journal of the English Academy of Southern Africa (Gardiner, 2010; Gottschalk, 2013). Two notable single-author collections have been published by Johannesburg's Botsotso: Horwitz's Out of the Wreckage: Dream Parables (2008), which mixes flashes and suddens, and Jobson's 100 Papers: A Collection of Prose Poems and Flash Fiction (2008). Recent collections of longer stories often include flashes: Stacy Hardy's Because the Night (2015) includes eight, Nick Mulgrew's Stations (2016) two. While Jobson's 100 Papers is predominantly "flash fiction" rather than "prose poems" (in which the emphasis is on language and imagery, instead of character or narrative), Sole's Land Dreaming: Prose Poems (2006) includes pieces closer to flash; two were reprinted in Flash magazine, which has also published flashes by Moolman that appear in his poetry collections (2007, 2010, 2013). Lava Lamp Poems (2011) by Colleen Higgs, who appears thrice in Women Flashing, includes cross-over pieces that read like flash memoir.

The best-known South African who might be considered a perennial writer of flash fiction and nonfiction is Ivan Vladislavić. Missing Persons (1989), Vladislavić's debut story collection, includes two flash cycles - "Sightseeing" and "A science of fragments" composed of 9 and 10 individually-titled flashes. Portrait with Keys: The City of Johannesburg Unlocked (2006) is comprised of 138 "linked vignettes (essays, short stories)" (Titlestad, 2012: 687) of flash and sudden lengths. "Itineraries", an appendix that "traces the order of the previously published cycles and suggests some other thematic pathways through the book" (Vladislavić, 2006: 191), encourages reading each of the numbered vignettes as part of multiple alternative series, as recommended by author or improvised by reader, and of none. Oddments and offcuts from Vladislavić's most recent books also have the makings or finish of self-contained flash fictions. The dated headnotes and notebook "scraps" (17) of the 11 "failed stories" (9) that comprise The Loss Library and Other Unfinished Stories (2011) the first aptly inspired by Swiss "microscript" writer Robert Walser (2010) - often go beyond abstract outlines into evocative adumbrations, while the 11 "Deleted Scenes" featured in 101 Detectives: Stories (2015: 195-204) could stand alone as fully-fledged flashes.

Some factors that fuelled the flash's global rise might help explain its South African efflorescence. As Women Flashing and Writing the Self indicate, the flash's brevity suits workshopping, popular with community writing-groups and the standard pedagogy of 
Creative Writing degrees, which in South Africa started in 1985 (Pieterse, 2013); Jobson's 100 Papers was, indeed, originally part of a master's dissertation (2006). The flash is often associated with (post)modernity, and the US turn and return to very short stories arguably reflected the social fragmentations of the interwar period and late capitalism, and the urgency of lives menaced by world wars, nuclear proliferation, and the AIDS pandemic; for some, society felt too atomised, life too brief, for grander, longer narratives (see Chappell et al., 1986). These factors are broadly applicable to contemporary South Africa, where gross inequalities persist while neoliberal individualism has eroded (anti-)apartheid solidarities, where the AIDS pandemic (exacerbated by denialism) is most acute, and where violent crime also heightens fear of premature death. "The undisputed genre marker for the short story is the imminence of the end" (Lohafer, 2003: 146), and the existential implications of narrative brevity are most obvious in flash, where the end is well-nigh; in one-page stories, it is visible from the outset.

The short story has been ascribed a particular cogency in what Loren Kruger (2002) has called "post-anti-apartheid" culture. Chapman (2004: xi) posits that "the big narrative of the novel perhaps was the most appropriate response" to the "big theme" of apartheid, whereas the short story, which "favours flexibility, ellipses, surprise, emotion, implication", is best-suited to the complexities of post-apartheid; and Michael Titlestad suggests that the unresolved suspension characteristic of the modernist short story is apt to South Africa's ongoing transition (2010: 190-1). Certainly, the short story is "less subject to the pressure of being interpreted as national allegory (or at least, state-of-the-nation report) than the novel" (Barnard, 2012: 666). While it might equally be argued that these very characteristics suited the short story to multifarious subversions of apartheid's grand narrative, Chapman's and Titlestad's contentions are further complicated by periodization of the after-apartheid into two phases: a "transitional" period encompassing the "pre-post-apartheid" negotiations of 1990-94 (Clingman, 2012: 647) and a "post-apartheid" decade of declining optimism; followed by a "post-transitional" (MacKenzie and Frenkel, 2010), or "post-postapartheid" (Chapman, 2009), period of disillusionment emerging from the early 2000s as "transition" increasingly looked "a rhetorical strategy [...] to positively connote an evolution and to mask and justify a social, economic, or political 'lack'” (Popescu, 2010: 161-2). For Leon de Kock, this was "plot loss writ large: most obviously, the loss of what had been celebrated so widely as the rainbow nation, or the miraculous Mandela revolution, or even just a halfdecent, nonpartisan democracy administered by accountable civil servants" (2015: n.p.); and this profound sense of losing the national plot tended writers to extremes, "either towards a 
playing up of plot (genre on the one hand, and incident-heavy nonfiction on the other), or a downplaying of it, a kind of under-plotting that was most evident in literary fiction" (2015, n.p.; see also De Kock, 2016). If the novel was perhaps appropriate to apartheid, and the short story to transition, the flash - a minimally plotted narrative that maximizes implication - is therefore apt to the under-plotted indeterminacy of the post-transition. The striking correlation between transition's demise and flash's rise may be as much coincidence as causation, but it at least suggests that the advent of post-transition was conducive to, perhaps a stimulus for, the flash.

The flash is also a manifestation of what Sarah Nuttall has called the "rise of the surface" (2012; see also 2009: 83-107), the valorization of "surface" and its affect associated internationally with the "reality hunger" (Shields, 2010) of contemporary multimedia societies insatiable for "NOW moments" (Margolin, 1999). For Nuttall, "rediscovery of the surface" (2012: 410) entails rejecting "symptomatic reading" - reading with a hermeneutics of suspicion to expose the repressed psychology, political ideology, or lacunae lurking deep in the texture of literary texts; and this rejection marks a local generational rift between an apartheid-era, largely white canon of the symptom and a revisionist post-apartheid art of the surface. It thus implicitly revises Njabulo Ndebele's (1986) seminal call for a "rediscovery of the ordinary", rehabilitating "surface" from his critique of a "largely superficial" (Ndebele, 1988/1984: 329) black "protest" literature mired in a documentary "tradition of almost mechanistic surface representation" (Ndebele, 1988/1984: 333) and a demonstrative "convention of the spectacular" (Ndebele, 1986: 150). De Kock, however, critiques Nuttall's binary between reading "across" and reading "down", arguing that "literature may yet be seen to have within it both the urgency of the 'surface' and the 'real', and the supposedly older forms of thick texture" (2012: 7). This is especially true of good flash fiction, which in its quick delivery of a concentrated "single effect", often onscreen, offers an urgent surface real to be read across; and in its reliance on (rather than repression of) implication, its requirement that readers fill in gaps, prompts depth reading. The ascendency of the flash might therefore be thought of as the rise of the deep surface.

This article will undertake close readings (or decompressions) of three posttransitional flashes, each under 450 words, that take key aspects of the (post)transition as their subjects. It suggests that such flashes might be considered "hyper-compressions" in that they compress and develop complex themes with a literary history and a contemporary currency. They can be distinguished from several other forms of encapsulation: serious literary histories, whether narrative or encyclopaedic; such parodic précis as Twitterature 
(Aciman and Rensin, 2009), Condensed to Flash (Budman and O'Niell, 2015), and "digested reads" (on J. M. Coetzee, for example, see Crace, 2005: 18-19; 2010: 350-4); and Henrietta Rose-Innes's (2014) 417-word “Once upon our time”, "a gloomy tale made up of the [50] first lines of each of the Twenty in 20 longlist”. Flash fiction is inherently metonymic, offering a brief narrative as a part that suggests the whole implied story; and the flashes discussed below are suggestive of, and allusive to, a broader literary culture. Given the postapartheid burgeoning of "South African literature" and the impossibility of comprehensive close reading - which led De Kock (2009) to consider Moretti's (2000) alternative of "distant reading" - the hyper-compressive flash, while no substitute, offers a tantalizing shortcut to a literature it also augments.

\section{Flashback: Tony Eprile's "The interpreter for the tribunal" (2007)}

The Truth and Reconciliation Commission has been approached in a plethora of generically diverse texts, the best-known including Ingrid de Kok's poems in Transfer (1997) and Terrestrial Things (2002), Antjie Krog's memoir Country of My Skull (1998), Sindiwe Magona's epistolary Mother to Mother (1998), and Gillian Slovo's thriller Red Dust (2000). In Country of My Skull, victim testimony is presented as reported speech, transcript, and even poetry. For Shane Graham, this formal variation between and within texts is an attempt "to avoid the anaesthetizing effect of being presented with one horrifying tale after another" (2009: 84). Tony Eprile, South African-born US-domiciled author of "Temporary Sojourner" and Other South African Stories (1989), has defamiliarized the TRC in two further forms that mitigate against psychological numbing: The Persistence of Memory (2004), a three-part Bildungsroman that dissects the habitual complicities of a "liberal" (2004: 170) nationalserviceman, which result in him becoming accessory to war crimes on the Namibia-Angola border; and "The interpreter for the tribunal", a flash published in three versions (2007a, 2007b, 2015) of just over 400 words, "a technical tour-de-force" (Baker, 2015: 79) that presents only the interwoven words of a political abductee and his torturer, voiced by their TRC translator. Whereas the Bildungsroman culminates in the set-piece Amnesty Committee hearing on which it is predicated, the flash concentrates not just on a hearing but on a condensed moment extracted from it. It dispenses with extrinsic Bildung, and with such intrinsic procedural aspects as chairperson, legal counsel, third-party witness statements, and 
psychiatric reports, in order to distil the TRC's essence: the encounter between perpetrator and survivor.

Eprile's flash was commissioned in August 2006 by Esquire, the American "generalinterest lifestyle magazine for sophisticated men" (Hearst, 2016), whose Napkin Fiction Project invited authors to complete stories on white cocktail napkins measuring 10-inches square when unfolded. Eprile's story, written, signed, and dated 28 September 2006 in noncursive black ballpoint, fills one unfolded side. The photographed napkin was published online, with transcript, on 20 February 2007 (Eprile, 2007a), and is digitally archived with around 130 others (Esquire, 2007/2008). Eprile's resembles a primary source, as if hastily jotted by a notebook-less reporter at a TRC hearing, or afterwards from memory in a bar. Seriousness is compromised, however, by the Project's construction as a commercial gimmick that exploits the cult of the (urbane, inspired) author. The napkins bear a red Esquire insignia in their bottom right-hand corners, inside the thin paper's coined edges, prebranding disparate narratives with a homogenizing corporate logo; and Eprile's handwritten phrases "I just wanted" and "who I am" abut the faux calligraphy of the "Esquire" that twice breaks his final sentence like an interpolation or marginalia, rewriting physical and psychological desperation as consumerist aspiration. This commodification is exacerbated by the website environment, which juxtaposes stories with frequently refreshed advertisements and article-links, distracting attention elsewhere and refocusing it in curious ways; in August 2016, Eprile's traumatic history was leavened, absurdly, by pain relief and pension plans, "timeless, easy-to-wear watches" and "chakra healing".

A revised version appeared in Eprile's essay "On justice, memory and compassion" (2007b), a "position paper" written for the symposium "Justice - one or many?", held 7-13 May 2007 in Greece, and published online in an "electronic book" (University of Iowa, 2007). The revisions are extensive (every sentence has been edited, and several subdivided), but not substantive; they enhance rather than alter the story's "single effect".

\section{The interpreter for the tribunal}

Interpreter for Amnesty Applicant Major J Herzbreek-Mr L.M. Speke Interpreter for Witness Mr Y Inkululeko-Mr L.M. Speke

I was hiding in my friend's garage, a place no one would think to look. I had my informants, you see. We were boys together and I knew he'd never betray me. I waited until the time they usually brought him food and when he opened the door to my whistle, I was on him like a pack of wild dogs. He ground my face into the 
concrete, shouting horribly in my ear. The pain was terrible. I did not know what was happening. The trick is to disorient the prisoner right away. Get him off guard and he'll tell you anything you want to know. My arm was twisted behind my back and I could feel the ligaments tearing. I did not struggle but he kept twisting, his knee my knee in his back you bastard you're done now he screamed I was thrust from the darkness into the light, then into the darkness again like a sack of potatoes I threw him into the trunk of my car, I'm that strong. I could hear him thumping in the trunk as I drove and hit the brakes taking the corners hard I bashed my head against something hard and was thrown helplessly into the light of a two-thousand candlepower torch right in the eyes hitting him all the time the fists coming from nowhere and I felt a rib breaking, my nose breaking. The blood ran down his face and he didn't even lift a finger to wipe it off my glasses had come off when they got me and I had no idea where I was on the ground of that hut, and yes I sat on his back and pulled the sack over his head, the wet sack like I was drowning I could not breathe. He could not breathe, I pulled it off now you will tell me what I want to know because otherwise I could not breathe I told him everything it did not take long to get the names my friends who betrayed me the friends I did not know what I was saying what he was saying those were hard times and we had to be hard to live in them I just wanted the pain to stop but I have to live with who I am now who was I then it is too terrible to speak of it at all is to go mad. (Eprile, 2007b)

Eprile's "position paper" advocates "idealistically" that "retributive justice" be replaced with "restorative justice", exemplified by the TRC. It argues that offenders are themselves victims, of a society similarly in need of reform; but is less certain about the process's benefits for offenders' victims, quoting TRC testimony that questions whether a bereaved mother "was better off before she told her story than she was after telling it". Eprile's flash, however, "arose out of a statement [he] had heard Desmond Tutu make [...]: that many of the interpreters for the TRC suffered mental anguish and breakdowns from having to speak in the first person for both violator and victim”. Krog similarly notes the impact on "a young Tswana interpreter": "“It is difficult to interpret victim hearings,' he says, 'because you use the first person all the time. I have no distance when I say "I" . . it runs through me with I. [...] After the first three months of hearings, my wife and baby left me because of my violent outbursts"” (1999/1998: 195). De Kok's poems “The transcriber speaks" and "The sound engineer" describe the strain on other professionals who recast oral 
TRC testimony, into complete written and edited aural forms: the transcriber is "the commission's own captive"; "The sound engineer hears / his own tympanic membrane tear" (2002: 32, 33). But, like De Kok's “What kind of man?” (2002: 25-7), Eprile's "translated" story also evokes (albeit implicitly) the high-profile amnesty case of police captain Jeffrey Benzien. Krog saw Benzien's July 1997 hearing as a watershed that "seizes the heart of truth and reconciliation - the victim face to face with the perpetrator - and tears it out into the light" (1999/1998: 109), and described the "spectacle" of Benzien demonstrating "the wet bag method" on a black volunteer as "one of the most loaded and disturbing images in the life of the Truth Commission" (1999/1998: 110); Graham notes that it "became an iconic moment", with the case "becoming a kind of tabula rasa on which observers inscribe their own feelings about the TRC's work" (2009: 23). Eprile inscribes on it a double concern with restorative justice, and the second-order trauma of its facilitators - that he addresses in two fictional modes. His flash provides the essay's last words since he prefers the "ambiguity and nuance $[\ldots]$ of fiction" to a "position paper"; but he twice describes it as a "brief fable", one of fiction's less ambiguous, more positioned forms, defined by Abrams and Harpham as "a short narrative [...] that exemplifies an abstract moral thesis or principle of human behavior" and usually concludes with "the moral in the form of an epigram" (2005: 7). As a "fable" that concludes "it is too terrible to speak of it at all is to go mad", the flash confirms Tutu's "statement" about second-order trauma. It also constitutes a meta-engagement with the ethics of writing, and reading, about atrocity (explored by Coetzee, 1986, 2003), suggesting that brevity might not mitigate its hazards. But ambiguity about these final words' attribution, and nuances throughout, problematize Eprile's "position" on offender victimhood and victim catharsis.

Whereas a fable is monological, subordinating characters' voices to their author's purpose, "The interpreter for the tribunal" is comprehensively dialogical. Its three "voices" are not only in dialogic interaction with social discourses and textual representations of the TRC, but also with each other. Every utterance is double-voiced, in that the words of perpetrator and survivor are reported, in translation, by the interpreter (the de facto narrator). Some are effectively treble-voiced, when ownership of a reported phrase is initially unclear or remains debatable. And the mediated "voices" of perpetrator and survivor are themselves polyphonous. This polyphony of and within voices is reflected in Eprile's invented names (searches of the TRC website return no matches). "Speke" puns on "speak" and invokes Victorian explorer John Hanning Speke, best known for "discovering" the source of the Nile; this is apt for the interpreter whose voicing dis-covers obscure sources, but also perhaps 
locates the origins of human-rights violations in colonial history and posits the TRC as a putative end-point. The other names indicate race and language: "Herzbreek" being white, an Afrikaner, speaking Afrikaans; "Inkululeko" being black, a Zulu or Xhosa, speaking isiZulu or isiXhosa. They also encapsulate key ambiguities. Major J Herzbreek (German herz + Afrikaans breek) might be translated as "major heartbreak" or, loosely, "major change-ofheart", suggesting his roles as heartbroken (damaged and/or distressed) heartbreaker and putative reformee. Inkululeko (isiZulu and isiXhosa) means "freedom" or "independence", but is also ironic, questioning whether the survivor is free: his initial, "Y", could stand for an affirmative "yes", but the pun on "why" queries liberation's point.

These ambivalences generate a dynamic conflict within and between unequal "voices", as Inkululeko and Herzbreek strive for self-control and for control over their shared story. Each of the first 10 sentences, of short and medium lengths, is devoted to one voice, and it is clear who "speaks". Each of the final four, longer sentences contains at least four units of speech, alternating between speakers who become increasingly entangled. The story could be considered a prose sonnet, with a volta initiating a final quatrain - reminiscent of Christopher van Wyk's much-quoted and anthologized sonnet "In detention" (1979; Brink and Coetzee, 1986: 50), an escalating satire of state explanations for detainee injuries and deaths. Inkululeko attempts to construct a denotative, factual account, listing assaulted body parts (face, ear, arm, back, ligaments) and telling rather than showing suffering ("The pain was terrible"). But in the final four sentences, bodily details (head, eyes, rib, nose) are overtaken by vivid evocation as he struggles to chart location (from "friend's garage" to lightless car-trunk to breathless hut-floor) and becomes re-immersed in disorienting trauma. Inkululeko's attempt to narrativize the experience is an attempt to regain agency and work towards closure, transforming "hot memory" into "cool memory" (Mengel et al., 2010: vii). But his telling exposes aporias ("a place no one would think to look") and lacunae ("I did not know what was happening", "I had no idea where I was", "I did not know what I was saying") that only Herzbreek can explain ("I had my informants, you see"; "The trick is to disorient the prisoner"). As Graham notes:

the imperative to convey the survivor's subjective experience of trauma also contains an internal paradox: to narrate a story requires an agent, but in testimonial literature the narrative describes the destruction of the author's agency. In this sense, the true agent of a torture victim's story is the torturer, a fact that threatens to exile the victim to the margins of his or her own tale. (2009: 29) 
Herzbreek's indispensable testimony is tainted, moreover, by personal vanity ('I'm that strong”), by contempt ("he didn't even lift a finger"), and by professional pride and derision ("it did not take long to get the names"). There are also hints (the slippage from singular to plural in "I was on him like a pack of wild dogs" and Inkululeko's "they got me") that he is shielding co-perpetrators. Herzbreek's agency problematizes his blaming of himself on history ("those were hard times and we had to be hard to live in them"), suggests his motivation was not exclusively political, and questions his contrition and commitment to full disclosure. Inkululeko's dependence on the equivocal Herzbreek suggests that his own retelling might reinforce rather than dissipate trauma. Being pulled from "hiding" and "darkness" and "thrown helplessly into the light of a two-thousand-candlepower torch" seems an apt but ironic metaphor, with undertones of Christian salvation and millennial fresh-starts, for the TRC: the traumatic eliciting of Inkululeko's story creates uncomfortable affinities between the TRC's gentle probing and his torturer's interrogation. Like Achmat Dangor's Bitter Fruit (2001), it questions the therapeutic value of re-opening old wounds, which in Dangor's novel leads to family breakdown and murderous revenge. Eprile's entangled "voices", each unresolved, are ultimately irreconcilable, which produces an open-ended discourse rather than an epigrammatically conclusive fable.

This openness was increased when "The interpreter for the tribunal" was anthologized in Flash Fiction International (Eprile, 2015). The body of the "On justice" version is reproduced unchanged, but both "Interpreter for" lines have been omitted. ${ }^{1}$ The author's name appears in their place beneath the title, sacrificing the flash's verisimilitude as historical document. Also lost are the lines' epigraph-like functions. The deletions remove the potential distraction of the puns, but at the expense of their broad allegorical connotations.

Anonymizing the "voices" might facilitate extrapolation to other contexts, but sacrifices important racial and linguistic specificities, the inference that two languages are being translated, and clarity that a high-ranking officer acted as state agent against a private citizen. It also removes identification of the interpreter's gender. The absence of "Amnesty Applicant" and "Witness" obscures the tribunal's particularity as a defined part of a unique process, even risking it being misconstrued as retributive-justice trial rather than restorativejustice hearing. Much of what is lost is to be inferred from "SOUTH AFRICA", which,

\footnotetext{
${ }^{1}$ The omission was Eprile's decision, rather than the editors': "I wanted to allow the story to be about places other than South Africa (and though I enjoyed making the puns in the various names, I wondered whether that might not distract from the story being told)" (Eprile, 2018, personal communication).
} 
printed in capitals above the title, stands as explanatory key or a priori determinant, like a "made in" or "product of" stamp. But this grand narrative overshadows the scrutiny of individual agency, introducing the story as the tragic result of a flawed national history. These textual erasures and paratextual additions inflect the remembering of a process that was variously regarded as excavation or burial, as instructive reminder or repository for amnesia. The story's re-presentation might be considered an update, as detailed memory of apartheid and the TRC dwindles, particularly overseas. Flash Fiction International's one other story from "SOUTH AFRICA" is Polish-born Szczurek's "Not far from the tree" (2009, 2015), in which the lonely wife of a business-traveller decides to commit adultery. The conjunction of these flashes - public and private, racial and sexual, political and domestic -

reflects the contemporary image of South Africa in the "global imaginary" (De Kock et al., 2001), bifurcated between, in Ndebele's (1986) terms, fading "spectacular" past and supposedly "ordinary" now.

\section{Flash noir: Michael Cawood Green's "Music for a new society" (2008)}

Graham notes that such "emblematic moments" from the TRC "focus our narratives of the past on certain 'gross' violations, while ignoring other profound material and psychological effects of apartheid and colonial rule" (2009: 30). Michael Cawood Green, whose long historical novel For the Sake of Silence (2008a) recreates a Trappist mission in colonial Natal, explores the post-apartheid legacy of these "profound material and psychological effects" in a 360-word flash published in the inaugural issue of Flash: The International Short-Short Story Magazine:

\section{Music for a new society}

It was as if the wall of glaring whiteness he had thought could never be climbed was suddenly something he could just walk through.

Changes of which he was half-aware-newspaper-headline changes, triumphant, distant, changes meaningful for others, not for those like him, but changes nevertheless - made the magic that had kept the wall in its place lose its power, undoing the artifice sustaining it. 
Now those once behind the wall stood exposed, quivering in their vulnerability, ordering those who would still serve them to create higher, thicker walls out of the far less effective mediums of concrete, brick, stone, wire, steel.

The things they owned waited for him. Taking them was the revolution that they were told had never happened. Not the things, but the taking.

He could depend upon their lingering sense of invincibility to betray them: dogs, alarms, bars bypassed, he slipped ineffably as the future into their sleep-warm houses. Then he stood above them, breathing in their dreaming before doing whatever it occurred to him to do.

Tonight, not even that much effort: a car pulled over just as the first heavy drops fell from the darkness through which he strode, humming, sure in his own strength. A child, two or three years old, let out to urinate, its mother hovering, irritated. So easy, for the figure coming out of nowhere: the flash in the driver's window, the jerk and spattering too little warning for the stark white face turning at the passenger door. The pale damp vision coming apart, the body folding in slow motion to the scrub and litter that lined the tarmac as it held on grimly to the last of the day's heat.

Easy, too, the dragging out and tossing of the driver over his mate. The satisfying work finally coming with taking the frozen child from the back seat and placing him next to his brother, short pants still down at his knees. Leaving them standing beside the leaking bundles of smart casual wear as he drove away, letting the play of guilt and blame become stronger than any illusion of a wall. (Green, 2008b)

The story centres on a crime for which South Africa is notorious, prominent in such novels as Michael Williams's Hijack City (1999) and Christopher Radman's Held Up (2012), and films including Hijack Stories (Schmitz, 2000) and Tsotsi (Hood, 2005), in all of which the car is not just portable property but a potent symbol of affluence and agency. To the extent that Green's story is crime fiction, it is South African noir, territory serially traversed by Deon Meyer's Afrikaner detective Bennie Griessel (Infanta, 2004; translated as Devil's Peak, 2007) and Margie Orford's psychologist Dr Clare Hart (Like Clockwork, 2006), rather than the cosy-crime realm of Sally Andrew's amateur sleuth, agony-aunt Tannie Maria (Recipes for Love and Murder, 2015). In flash noir, however, there is no room for the complexities of the plot-driven police procedural steered by an emotionally-damaged investigator. Nor is there resolution: this truncated crime-narrative is also - to repurpose 
David Gaffney's (2006) term for a 150-word flash - a "sawn-off tale", ending with the explosive incident and forgoing any reassuring restoration of order. Nevertheless, the absence of a case-solving detective does not preclude social detection, the revelation or diagnosis of society's ills that is particularly marked in South African crime fiction. "Music for a new society" is not a whodunnit or a howdunnit, or even a will-he-get-done-for-it, but a whydunnit.

The story proceeds from whydunnit backstory to what-was-done moment, inverting the crime-investigation chronology of most detective fiction and the action-epiphany sequence common in short stories. The backstory, more "spot of time" than Bildung, reflects the general agreement that "crime in South Africa is ineluctably historical" (Barnard: 692). In Niq Mhlongo's Dog Eat Dog (2004), with expectations raised by the 1994 election the black student narrator-protagonist Dingz muses: "Everything is 'affirmative' nowadays [...] Shoplifting is called 'affirmative transaction'. Carjackers make 'affirmative repossessions'" (79). In Coetzee's Disgrace (1998), Lurie rationalizes theft as the "schematic" redistribution of "things", including his car, in "a vast circulatory system" (98), and diagnoses the vengeful "personal hatred" his daughter saw in her unknown rapists as "history speaking through them [...] A history of wrong" (156). A more subtle determinism is posited, as literal thesis, early in Orford's Like Clockwork: Hart's doctorate, "Crimes against Women in Post-Apartheid South Africa", argues that "because we averted a civil war [...] the "unspent violence was sublimated into a war against women"" (2009/2006: 21-2). In "Music for a new society" the writer-as-detective constructs a psychological profile that similarly suggests that the violent "taking" of "things" is an affirmative substitute for the denied "revolution".

This profile is focalized mostly through the taker, whose epiphany "suddenly" reveals apartheid's "wall of glaring whiteness" as an ideological construct of "magic", "artifice", and “illusion” founded on "power", and exposes whites' post-apartheid "vulnerability" behind mere material "walls [...] of concrete, brick, stone, wire, steel" and "dogs, alarms, bars". He divides blacks into elite beneficiaries and marginalized poor ("changes meaningful for others, not for those like him"), and the black poor into servile ("those who would still serve") and criminal (who pursue his retributive, redistributive "revolution"). The casual violence "whatever it occurred to him to do" during home-invasions, the carjacking's "easy" murders and "tossing" of a body - is enabled by depersonalization of whites, reduced to an amalgam of position ("those once behind the wall", "driver"), racialized phenomena ("stark white face", "pale damp vision" - manifestations of "glaring whiteness"), animal ("body", "mate”), and class-signifier ("bundles of smart casual wear"). The sparing of the boys might offer 
hope of redemption, as the nurturing of a carjacked baby does in Tsotsi; but "taking" one of the young heirs from the car, and the car from them, arranging them into a roadside tableau of dispossession, is "satisfying work" that seems to eclipse "taking" possession of the vehicle. It is also uncertain whether "the play of guilt and blame" he finally admits is mental game or serious proto-epiphany, which makes the profiled "other" ultimately unknowable and begs questions about the moral standings of history's damaged criminal, complicit beneficiary, and young inheritor. It reconfigures TRC debates about whether human-rights violations can be blamed on history rather than individual agency, and problematizes property rights too.

"Music for a new society" thus ends on a bleak impasse between ineluctable past and "ineffabl[e] [...] future", also implied by the title's multiple ironies. The "music" is not a celebratory symphony or inaugural anthem but a disharmony audible as the assured "humming" of the carjacker; no other sound is referred to in a story that moves from interiority to filmic "slow motion", which registers a gunshot only as a visual "flash". "New society" is an echo of the much-vaunted "New South Africa", the human and potentiallyoptimistic "society" being a sibilant four-syllable substitute for the geographical colonial name. South Africa's “new” democracy is celebrated in Gardiner's flash "The new candidate: Durban" (2010) and Higgs's "Jeppestown, 1994", the first of five distinct prose narratives that form her reflective "Notes from a New Country" (2011: 49-55); but the sequence's initial exhilaration is tempered by "The Mount Nelson Hotel, 2006" (53), which scrutinizes commodification of impoverished women's anti-apartheid struggle, and "Centurion, 2007" (55), which notes the ruling party's “friendly yet menacing goodwill”. The full-blown posttransitional irony of Green's title implies that the "new" is inextricable from the old, and "society" is broken. If even single-word nicknames can be stories (see Nelles, 2012: 101n9), "South Africa" and, especially, "the 'new' South Africa", which quickly acquired the double scare-quotes, are remarkable flash fictions. Green's "Music for a new society" might thus be read as an updated version, and retrospective vindication, of the 1980s "literature of dread" (Van Wyk Smith, 1990: 67, 97, 123, 131), as an example of the post-apartheid "liberal funk" (see Marais, 2001) of those whose "lingering sense of invincibility" has been eroded, leaving them "exposed, quivering in their vulnerability" - a fearful insecurity, and impetus for white flight, explored by journalist Kevin Bloom's Ways of Staying (2009). This implication is bolstered by the only part of the story focalized through a victim: "the figure coming out of nowhere: the flash in the driver's window, the jerk and spattering too little warning" for the mother. "Music for a new society" represents the post-apartheid criminal "other" with qualified understanding and unqualified dread. 
Whereas Green, who has noted "the dangers of appropriating the voices of 'others' in any particular construction of what the "new' South Africa will be" (2007: 54), here avoids the first-person, Kelwyn Sole's "Respect”, a one-page piece in Land Dreaming (2006: 66), presents a carjacker's voice. Appropriation is avoided, however, by its presentation as a prose dramatic monologue addressed to a paying auditor, presumably a journalist or sociologist, which problematizes the voice's authenticity and so pre-empts criticism. Kwaaiboy, whose slang-Afrikaans name translates literally as “"Angry' (or 'Nice') Boy” (116n), performs his gangster identity for the auditor, just as he describes doing for his gang:

My name is Kwaaiboy but my guys call me Respect. [...] When we are all into the car to do a job, I load my piece so's they all can see - like this, né? - and shout: "My name is Kwaaiboy, son of no one. Today I'll teach them to respect. I'll teach them to shit when they hear my name!" (Sole, 2006: 66)

Kwaaiboy styles his carjackers as "car dealers" who "don't do petty crime”, but bravado gives way to pathos. His defiant self-creation acknowledges the formative influence of family breakdown ("son of no one") and a township environment blighted by poverty, intra- and inter-gang violence, and AIDS. "Thug life" seems predestined and inescapable, and premature death inevitable: God "always takes my guys". It is not propertied victims, but gangsters whose days are explicitly numbered. Kwaaiboy's criminality is motivated by desires for "respect" (the story's title, and his storied nickname) and "money" (the story's raison d'être, and its bottom line): "When you have money though you can do anything." But this conclusion seems as desperate as it is defiant, as hollow for someone entrapped by his environment as it is true for many outside it. Sole's story is less explicitly historicized than Green's, but it likewise presents crime as rooted in the material deprivations and psychological damage inflicted by apartheid; and consequently as motivated by desire not just for "money" and "things", but also for the empowering experience and symbolism of taking them, whether in pursuit of "respect" or "revolution".

\section{Flash forward: Stacy Hardy's “Kisula" (2015)}

Stacy Hardy's Because the Night contains 21 stories, eight of which are under two pages, including five that each fit on one page. As Jobson (2015: n.p.) notes, "The shorter stories 
constitute 'flash fiction' due to their potent compression, rapid recoil and the collaboration required of the reader". "Kisula", the second-shortest story, at 317 words, uses compressive techniques common in flash: first-person narration, which economically combines character and narrator; a minimal number of characters and locations, deftly evoked; beginning late, in medias res; and ending early, on an implied epiphany.

\section{Kisula}

They'd already started when I got there. The usual crew, the usual subject: BC. How come Black Consciousness guys always have white girlfriends? The whole table looked from me to Andile. I said, forget it. I'm not his girlfriend we just fuck sometimes. Everyone laughed except Andile. He looked sad then he raised his beer, a salute. The bottle was nearly empty. It caught the sun and made circles on our table. I felt dizzy, skin tingling, gripping too tight. I didn't want to drink anymore so I left without paying. The street smelt like fish. The beer swilled in my stomach and my armpits itched. My building is an old office block converted to residential. The doors are glass, wood panelling floor to ceiling. I sit in the cool of the lobby and watch soccer with the Congolese security. He is a refugee. He calls himself Gary, even though his real name is Kisula. I think Kisula is prettier. I ask him to say it. I like how it sounds, round and low in his mouth. K-i-s-u-l-a. He tells me to shush. On the TV it is France vs Chile. Kisula is backing France. I think that's fucked up. I say, how can you support them after what they did to your country? He shrugs. They have the best team. He says, look. The French are taking a penalty. The stadium goes silent. Everything is frozen and throbbing like something stretched taut. The ball slices the screen, a single white orb, a streaking comet—whoomp! — and everything explodes. Next to me Kisula is shouting. He stands and raises his arms, his muscles turning and tilting in the light, angles and shadows, his eyes shining. I stand too. I dance on the spot with my hands in the air. We both dance. We dance and laugh together like we share something deep and real and eternal. (Hardy, 2015: 33)

"Kisula" falls into two main parts and settings, juxtaposing the narrator-protagonist's interactions with Andile's “crew" and Kisula, the first narrated in past tense, the second in present. The in medias res opening inserts her, as well as the reader, into the midst of an already-commenced activity, reinforcing her uncomfortable marginality, which Hardy has described as a reflection of her own "sense of being other" when in "anti-white conversation" 
(Gray van Heerden, 2015). The discomfort is also boredom, enacted by the second sentence's repetition of "usual", particularly with Black Consciousness, whose familiarity is indicated by the initialism "BC"; and the post-apartheid persistence of this anti-apartheid political philosophy (which dates from the late 1960s, and was most prominent in the 1970s) is indicative of broader post-transitional disillusionment. What the story explicitly takes issue with is the cliché that "Black Consciousness guys always have white girlfriends", and the implication that even post-apartheid cross-racial relationships - sometimes dubbed “"affirmative romance"” (Mhlongo, 2004: 79) - cannot be extricated from South Africa's history of anti-miscegenation laws and mythologies (see Blair, 2003b: 583-8; 2012: 480-1, 485-6). As the narrator-protagonist of Hardy's “My black lover" observes: "We joke about it but we both play the roles: him as all darkness, danger and downward trajectory, me as repressed little white girl rebelling against privileged upbringing, the private schools and fancy university education" (2015: 89). In this four-page story, role-playing is undercut by reality - "When we do actually get round to fucking it's not like the fucking I imagined" (91) - and in "Kisula" such roles, and their political overtones, are wearily dismissed: "I said, forget it. I'm not his girlfriend we just fuck sometimes." The stale repetition is figured by the near-empty beer bottle with which a "sad" Andile offers a valedictory "salute": it produces "circles" on the communal "table", the narrator's "dizzy" head (and "swilled" stomach), and a sensation that her "skin", primary marker of race, is "gripping too tight". This prompts her to leave "without paying", metaphorically for the apartheid past, attempting to break free from the relentless historicizing of desire.

This past-tense portion of the story ends with the briefest of street passages, which bridges the main settings: "The street smelt like fish." This olfactory impression of an implied journey in an unidentified, perhaps coastal, city is hardly the flânerie of Vladislavić's Portrait with Keys or Mark Gevisser's Lost and Found in Johannesburg (2014), both of which undertake detailed peripatetic mappings, but the switch to present tense introduces the common metaphor of urban environments as palimpsests (see Graham, 2009: 195n2): "My building is an old office block converted to residential". This suggests wider inner-city regeneration, while the wood-panelled lavishness implies the repurposing of a rundown Central Business District abandoned by big business. The deft slippage in the present tense from the expression of a condition now existing ("My building is") - which initially seems embedded in the past-tense narrative - to the description of an action now occurring ("I sit in the cool of the lobby") functions as a double-stitched seam that both joins and separates recent past (in which identities diverge) from immanent present (in which convergence is 
improvised). (On ideas of the "seam", see De Kock, 2001.) The setting moves indoors to the liminal space of a threshold place where the affluent meet those who protect their privilege where the disenchanted narrator seeks refuge, ironically with "a refugee" who has suffered greater displacement. The flash's brevity precludes anything approaching the detailed migrant-story of Jonny Steinberg's A Man of Good Hope (2015), which reconstructs a Somali's real journey from Mogadishu to Cape Town and eventually the USA, but Hardy similarly broaches ethical questions of agency and appropriation.

While the first part of "Kisula" invokes the cliché played out in Gordimer's A Sport of Nature (1987) in Hillela's role as handmaiden to a succession of African(ist) revolutionaries, the second recalls its post-apartheid revision in Gordimer's The Pickup, in which Julie Summers, affluent "acolyte of the remnant hippie community" (2001/2002: 197) that constitutes "The Table" at Johannesburg's "L.A. Café", meets an immigrant Arab car mechanic who calls himself Abdu, before emigrating with him to his unidentified country, where his real name, Ibrahim ibn Musa, is revealed (see Blair, 2003a). Hardy's "Congolese security", who "calls himself Gary, even though his real name is Kisula", is as much a palimpsest as the "converted" building he guards; and his name-changing invokes a common trope that is also suggested by Sole's Kwaaiboy styling himself "Respect" before a paying auditor. In Gordimer's July's People, for example, it takes a revolution to reveal to July's employers of 15 years what their servant "really was called": "Mwawate" (1981/1982: 120). This Man Friday convention of a subaltern adopting a single English name for the convenience of white employers was satirized in an early post-liberation Madam \& Eve cartoon (or graphic flash), in which Madam remains ignorant, having mistaken Eve's feted surname "Sisulu" (invoking struggle veteran Walter Sisulu) for a sneeze (Francis et al., 1998: 24). Moolman's flash “All girls' school”, which evokes the experience of an employee at a desegregated school who is addressed by white teachers as "Philemon" and by black pupils with variants of his "real name", offers a more subtle meditation on naming and identity (2007: 39). In "Kisula", however, it is the employee who "calls himself" by a Western name, and the white narrator's appropriation of his prerogative to self-making by favouring his "real name" (also valorized in the flash's title) is implicitly rebuked: "He tells me to shush." A broader implication is that the trope itself, however revisioned, is as hackneyed as the miscegenation cliché the narrator wants to "forget" and the Jim-comes-to-Jo'burg narrative, or transnational Gary-comes-to-town variant, she largely omits. 
The ostensible reason for the shushing is Kisula's absorption in live television coverage of an international soccer match. ${ }^{2}$ When the narrator protests Kisula's support for France as "fucked up", Kisula "shrugs" off colonial history and pragmatically backs "the best team". His choices of name and team act on what Graham refers to as "the amnesiac impulses of globalization" evident in "the post-apartheid, postmodern city" (2009: 4). In the opening scene of Phaswane Mpe's Welcome To Our Hillbrow (2001), Johannesburg immigrants are invited to share in anarchic celebrations of the home nation's triumph in soccer's 1994-95 African Cup of Nations. But Kisula - like the male title-character of Hardy's "My Nigerian drug dealer" (2015: 45-8), who sits in the infatuated female narrator's Cape Town home "watching the European Club Finals drinking a beer" (47) - is consumer of a globalized commodity rather than affiliated to a national team, with no apparent aspiration to belong to "imagined communities" (Anderson, 1983) of origin or (notwithstanding his name-changing) destination. In the story's visual final third, which follows Kisula's instruction to "look", the focus narrows to the concentrated moment of penalty and celebration. The football's "single white orb" is an apt image of globalization, and likening it to "a streaking comet" links it to a conventional harbinger of epochal change wrought by colliding worlds (as Halley's Comet is in Sol Plaatje's Mhudi (1930)). The shushed South African lobby presages the "silent" French stadium, and geographical distance is aurally and visually dissolved with an onomatopoeic "whoomp!" as "[t]he ball slices the screen" and "everything explodes". Kisula's celebratory dance links him to the distant crowd, and the narrator mirrors him so that, in the last two sentences, the "I" and the "he" become, tentatively, "we". Her "dance on the spot" is both movement and stasis, however, and the characters' connections with the global and with each other are qualified by the final sentence's simile: "We dance and laugh together like we share something deep and real and eternal" - the implication being that the "something" shared may be superficial, illusory, and transient. This refusal to satisfy the narrator's epiphanyhunger acknowledges the story's erotic subtext, as "throbbing like something stretched taut" gives way to "streaking" and climactic explosion, and the white female gaze objectifies the black male body - already tagged with the "prettier"-sounding name - "turning and tilting in the light". The "like something" simile is explicitly sexual, but the relationship mooted by the concluding "like we share something" simile is doubly tentative, having the tentativeness

\footnotetext{
2 The match, or at least the scored penalty kick, seems to have been invented for thematic resonance and dramatic effect: since the end of apartheid, France and Chile have twice played International Friendlies in France (1994 and 2011) and once in Chile (2001); France scored in all three matches, but never a penalty (Association of Football Statisticians, 2018).
} 
inherent in simile comparisons but lacking their usual specificity. The "something" the narrator twice imagines between herself and Kisula is libidinal and may or may not be more, but its inchoate provisionality is preferred to the certain dead-end of the repeated "usual".

On its simplest level, then, "Kisula" is a love story about a jaded woman who walks away (literally, and perhaps metaphorically) from a stale relationship and rebounds towards a potential new lover. But it is also a peripatetic mapping of urban space, historical time, and literary history. As Barnard notes, "cities generate an improvisational mode of being and belonging, quite different from that proposed by nationalism" (2012: 669), and both Kisula and the narrator implicitly reject the "imagined communities" of nations to adopt this individualistic "improvisational mode". The narrator's walk away from the retro pressures of the "table" (rendered in past tense) to the contemporary "cool of the lobby" (expressed in present tense), from uncomfortable margin to thrilling threshold, archives a backwardlooking nationalism, in which identity is fixed, and writes a forward-looking transnational cosmopolitanism, in which identity is multiple and exhilaratingly ad hoc. Hardy's flash thus acknowledges the historical "entanglements" of people and the temporal "entanglements" of past, present, and future (see Nuttall, 2009: 1-12), but also tentatively embraces an impulse to "forget", "shush", and "shrug" off the legacies of colonialism, to deliberately lose the national plot, and to revision its literary tropes.

\section{Conclusion}

Like Eprile's “The interpreter for the tribunal” and Green's "Music for a new society", Hardy's "Kisula" is an exemplary hyper-compressive flash whose deep surface and complex implications are richly evocative of post-transitional South Africa. Each flash is rooted in the psychological and material legacies of apartheid, and compresses and develops contemporary themes with a substantial literary history: the TRC as an intensely problematic "restorative" process; violent crime as historicized social phenomenon and fearful preoccupation; crossracial sex, transnational migration, and the psychogeography of the Africanized city under globalization. Each is implicitly concerned with the ethics of voicing or representing others without compromising or appropriating their agency. And each is unresolved, ending in the suspension characteristic of the modernist short story, but also incorporating pre-closure "gaps" for the implied reader cognitively to fill, often with recourse to contextual and intertextual knowledge. As these three hyper-compressions suggest, the best of the flash 
fiction that has thrived during South Africa's post-transition is of literary-historical significance - not just as an inherently metonymic form suggestive of, and allusive to, a broader literary culture, but as a serious genre in its own right.

\section{Acknowledgements}

For helpful feedback on this article, my thanks to the special issue's editors, the anonymous JCL reviewers, Ashley Chantler, Melissa Fegan, and Clara Neary.

For kind permission to include complete texts of flashes, I am grateful to the following: Tony Eprile's "The interpreter for the tribunal" and Michael Green's "Music for a new society" are reprinted by permission of the respective authors; Stacy Hardy's "Kisula" is reprinted by permission of the publisher, Pocko Editions.

\section{References}

Abrams MH and Harpham GG (2005) A Glossary of Literary Terms. Boston: Thompson Wadsworth.

Aciman A and Rensin E (2009) Twitterature: The World's Greatest Books Retold Through Twitter. London: Penguin.

Anderson B (1983) Imagined Communities: Reflections on the Origin and Spread of Nationalism. London and New York: Verso.

Andrew S (2015) Recipes for Love and Murder. Edinburgh: Canongate.

Association of Football Statisticians (2018) France national football team: Record v Chile. Available at: www.11v11.com/teams/france/tab/opposingTeams/opposition/Chile (accessed 4 June 2018).

Attwell D and Attridge D (eds) (2012) The Cambridge History of South African Literature. Cambridge: Cambridge University Press.

Baker B (2015) Book review: Flash Fiction International: Very Short Stories From Around the World. In: Flash: The International Short-Short Story Magazine 8(2): 79-80.

Barnard R (2012) Rewriting the nation. In: Attwell D and Attridge D (eds) The Cambridge History of South African Literature. Cambridge: Cambridge University Press, 652-675. 
Blair P (2003a) Book review: The anxiety of affluence: Gordimer's The Pickup. In: Current Writing: Text and Reception in Southern Africa 15(1): 178-182.

Blair P (2003b) That "ugly word": Miscegenation and the novel in pre-apartheid South Africa. Modern Fiction Studies 49(3): 581-613.

Blair P (2012) The liberal tradition in fiction. In: Attwell D and Attridge D (eds) The Cambridge History of South African Literature. Cambridge: Cambridge University Press, 474-499.

Blair P (2013) Flash fiction. In: Owen A (ed.) Writers' and Artists' Yearbook 2014. London: Bloomsbury, 279-282.

Bloom K (2009) Ways of Staying. Johannesburg: Picador Africa.

Bosman HC (2007) The Complete Oom Schalk Lourens Stories (Ed. MacKenzie C). Cape Town: Human and Rousseau.

Bosman HC (2011) The Complete Voorkamer Stories (Ed. MacKenzie C). Cape Town: Human and Rousseau.

Brink A and Coetzee JM (eds) (1986) A Land Apart: A South African Reader. London: Faber and Faber.

Budman M and O’Niell S (eds) (2015) Condensed to Flash: World Classics. Vestal Review Press.

Casto P (2008) Flash fiction. In: Womack E (ed.) Books and Beyond: The Greenwood Encyclopedia of New American Reading: Volume 2: E-M. Westport: Greenwood Press, 385399.

Chantler A (2008) Notes towards the definition of the short-short story. In: Cox A (ed.) The Short Story. Newcastle: Cambridge Scholars, 38-52.

Chapman M (2003/1996) Southern African Literatures. Pietermaritzburg: University of Natal Press.

Chapman M (2009) Conjectures on South African literature. Current Writing: Text and Reception in Southern Africa 21(1\&2): 1-23.

Chapman M (ed.) (1989) The "Drum” Decade: Stories from the 1950s. Pietermaritzburg: University of Natal Press.

Chapman M (ed.) (2004) The New Century of South African Short Stories. Johannesburg: Jonathan Ball.

Chapman M (ed.) (2007) Omnibus of A Century of South African Short Stories.

Johannesburg: Jonathan Ball. 
Chappell F et al. (1986) Afterwords: The tradition. In: Shapard R and Thomas J (eds) Sudden Fiction: American Short-Short Stories. New York: Gibbs Smith, 227-237.

Clingman S (2012) Writing in the interregnum: Literature and the demise of apartheid. In: Attwell D and Attridge D (eds) The Cambridge History of South African Literature. Cambridge: Cambridge University Press, 633-651.

Coetzee JM (1986) Into the dark chamber: The writer and the South African state. In: Doubling the Point: Essays and Interviews (Ed. Attwell D). Cambridge, Massachusetts: Harvard University Press, 361-368.

Coetzee JM (1999) Disgrace. London: Secker and Warburg.

Coetzee JM (2003) Lesson 6: The problem of evil. In: Elizabeth Costello: Eight Lessons. London: Secker and Warburg, 156-182.

Cornwell G, Klopper D and MacKenzie C (2010) The Columbia Guide to South African Literature in English Since 1945. New York: Columbia University Press.

Crace J (2005) The Digested Read. London: Guardian Books.

Crace J (2010) Brideshead Abbreviated: The Digested Read of the Twentieth Century. London: Guardian Books.

Dangor A (2001) Bitter Fruit. Cape Town: Kwela.

De Kock L (2001) South Africa in the global imaginary: An introduction. Poetics Today 22(2): 263-298.

De Kock L (2009) Judging new "South African" fiction in the transnational moment. Current Writing: Text and Reception in Southern Africa 21(1\&2): 24-58.

De Kock L (2012) So, what should academic critics be doing, on the edge of the now skimming the surface or plumbing those depths? English Studies in Africa 55(2): 3-17.

De Kock L (2015) Post-liberation writing plays hide-and-seek with plot. Mail and Guardian, 23 April. Available at: http://mg.co.za/article/2015-04-23-post-liberation-writing (accessed 28 May 2015).

De Kock L (2016) Losing the Plot: Crime, Reality and Fiction in Postapartheid Writing. Johannesburg: Wits University Press.

De Kock L, Bethlehem L and Laden S (eds) (2001) South Africa in the global imaginary. Poetics Today 22(2) [Special issue].

De Kok I (1997) Transfer. Cape Town: Snailpress.

De Kok I (2002). Terrestrial Things. Cape Town: Kwela/Snailpress. 
Eprile T (1989) “Temporary Sojourner” and Other South African Stories. New York: Simon and Schuster / Fireside.

Eprile T (2004) The Persistence of Memory. New York: Norton.

Eprile T (2007a) The interpreter for the tribunal. In: Esquire Napkin Fiction Project. Available at: http://www.esquire.com/entertainment/books/a9944/esq0207interpreter (accessed 5 June 2018).

Eprile T (2007b) On justice, memory and compassion. In: Justice: One or Many? Writing from New Symposium 2007. Available at: https://iwp.uiowa.edu/programs/internationalconferences/the-new-symposium/2007/eprile (accessed 5 June 2018).

Eprile T (2015) The interpreter for the tribunal. In: Merrill C, Thomas J and Shapard R (eds) Flash Fiction International: Very Short Stories From Around the World. New York: Norton, 184-185.

Esquire (2007/2008) Napkin fiction. Available at: www.esquire.com/search/napkin\%2520fiction (accessed 28 August 2016).

Fisher M (ed.) (2005) Women Flashing: A Collection of Flash Fiction from Women's Writing Workshops. Cape Town: Women's Writing Workshops.

Francis S, Dugmore H and Rico (1998) Madam \& Eve's Greatest Hits. Parktown, Johannesburg: Penguin.

Frenkel R and MacKenzie C (2010) Conceptualizing "post-transitional” South African literature in English. English Studies in Africa 53(1): 1-10.

Gaffney D (2006) Sawn-Off Tales. Cambridge: Salt.

Gevisser M (2014) Lost and Found in Johannesburg: A Memoir. New York: Farrar, Straus and Giroux.

Galgut D (2004/1995) The Quarry. London: Atlantic.

Gardiner S (2010) The new candidate. English Academy Review 27(1): 122.

Gordimer N (1982/1981) July’s People. London: Penguin.

Gordimer N (1987) A Sport of Nature. London: Jonathan Cape.

Gordimer N (2002/2001) The Pickup. London: Bloomsbury.

Gottschalk K (2013) Update: Snow White and her seven dwarves. English Academy Review 30(1): 135-136.

Graham S (2009) South African Literature after the Truth Commission: Mapping Loss. New York: Palgrave Macmillan. 
Gray van Heerden C (2015) Because the night belongs to us. In: Stellenbosch Literary Project, 29 July. Available at: http://slipnet.co.za/view/blog/because-the-night-belongs-to-us/ (accessed 5 June 2018).

Green M (2007) The bitter history of sweetness: Metaphor and materiality in Daphne Rooke's Ratoons. English in Africa 34(1): 43-57.

Green M (2008a) For the Sake of Silence. Cape Town: Umuzi.

Green M (2008b) Music for a new society. Flash: The International Short-Short Story Magazine 1(1): 9-10.

Hardy S (2015) Because the Night. London: Pocko Editions.

Hearst (2016) Esquire. Available at: www.hearst.com/magazines/esquire (accessed 5 June 2018).

Higgs C (2015) Lava Lamp Poems. Athlone, Cape Town: Hands-On Books.

Holdefer C (2014) How short is short? Journal of the Short Story in English 62: 149-161.

Hood G (dir.) (2005) Tsotsi. Los Angeles: Miramax.

Horwitz AK (2008) Out of the Wreckage: Dream Parables. Johannesburg: Botsotso.

Isaacson M (1992) "Holding Back Midnight” and Other Stories. Johannesburg: COSAW.

Jobson L (2006) 100 Papers: An Anthology of Flash Fiction and Prose Poetry with a Theoretical Postscript. Unpublished MA Thesis, University of the Witwatersrand, Johannesburg, South Africa.

Jobson L (2008) 100 Papers: A Collection of Prose Poems and Flash Fiction. Johannesburg: Botsotso.

Jobson L (2015) Book review: Because the Night. Business Day, 12 June. Available at: www.bdlive.co.za/life/books/2015/06/12/book-review-because-the-night (accessed 31 May 2016).

Krog A (1999/1998) Country of My Skull. London: Vintage.

Kruger L (2000) "Black Atlantics", "White Indians" and "Jews": Locations, locutions and syncretic identities in the fiction of Dangor and others. Scrutiny2: Issues in English Studies in Southern Africa 7(2): 34-50.

Langa M, Kgoleng K, Matshoba M and Snyckers F (eds) (2014) Twenty in 20: The Best Short Stories of South Africa's Twenty Years of Democracy. Johannesburg: Times Media Books.

Lohafer S (2003) Reading for Storyness: Preclosure Theory, Empirical Poetics, and Culture in the Short Story. Baltimore: Johns Hopkins University Press. 
Mabaso DZ (ed.) (2013) My Holiday Shorts: A Collection of South African Short Short Stories. Johannesburg: Black Letter Media.

Magona S (1998) Mother to Mother. Cape Town: David Philip.

Marais M (2001) Very morbid phenomena: "Liberal funk", the "Lucy-syndrome" and JM Coetzee's Disgrace. Scrutiny2: Issues in English Studies in Southern Africa 6(1): 32-38.

Margolin U (1999) Of what is past, is passing, or to come: Temporality, aspectuality, modality and the nature of literary narrative. In: Herman D (ed.) Narratologies: New Perspectives on Narrative Analysis. Columbus, Ohio: Ohio State University Press.

Masih TL (2009) In pursuit of the short short story: An introduction. In: Masih TL (ed.) The Rose Metal Press Field Guide to Writing Flash Fiction. Boston: Rose Metal Press, xixxxviii.

Mengel E, Borzaga M and Orantes K (eds) (2010) Trauma, Memory, and Narrative in South Africa: Interviews. Amsterdam and New York: Rodopi.

Merrill C, Thomas J and Shapard R (eds) (2015) Flash Fiction International: Very Short Stories From Around the World. New York: Norton.

Meyer D (2007) Devil's Peak (Trans. Seegers KL). London: Hodder and Stoughton.

Mhlongo N (2004) Dog Eat Dog. Cape Town: Kwela.

Mills M (ed.) (2003) Crafting the Very Short Story: An Anthology of 100 Masterpieces. Upper Saddle River, New Jersey: Prentice Hall.

Moolman K (2007) Separating the Seas. Pietermaritzburg: University of KwaZulu-Natal Press.

Moolman K (2010) Light and After. Grahamstown: Deep South.

Moolman K (2013) Left Over. Sandton, Johannesburg: Dye Hard Press.

Moretti F (2000) Conjectures on world literature. New Left Review 1: 54-68.

Mpe P (2001) Welcome To Our Hillbrow. Pietermaritzburg: University of Natal Press.

Mulgrew N (2016) Stations. Cape Town: David Philip.

Ndebele NS (1986) The rediscovery of the ordinary: Some new writings in South Africa. Journal of Southern African Studies 12(2): 143-157.

Ndebele NS (1988/1984) Book review: Turkish tales, and some thoughts on South African fiction. In: Oliphant A and Vladislavić I (eds) Ten Years of Staffrider 1978-1988. Ohio: Ohio University Press, 318-340.

Neate P (2007) Jo'burg. In: Wild P (ed.) The Flash. London: Social Disease, 25. 
Nelles W (2012) Microfiction: What makes a very short story very short? Narrative 20(1): 87-104.

Nuttall S (2009) Entanglement: Literary and Cultural Reflections on Post-apartheid. Johannesburg: Wits University Press.

Nuttall S (2012) The rise of the surface: Emerging questions for reading and criticism in South Africa. In: Van der Vlies A (ed.) Print, Text and Book Cultures in South Africa. Johannesburg: Wits University Press, 408-421.

Orford M (2009/2006) Like Clockwork. London: Atlantic.

Pieterse H (2013) Die dosering van Skryfkuns aan Suid-Afrikaanse universiteite: 'n Oorsig [Teaching Creative Writing at South African universities: An overview]. Literator 34(2): 112.

Plaatje, ST (1930) Mhudi: An Epic of South African Native Life a Hundred Years Ago. Lovedale: Lovedale Press.

Popescu M (2010) South African Literature Beyond the Cold War. New York: Palgrave.

Radmann C (2012) Held Up. London: Headline Review.

Rose-Innes H (2014) 20/20: A tiny story made of 50 first lines. In: Books Live, 7 July. Available at: http://henriettaroseinnes.bookslive.co.za/blog/2014/07/07/2020-a-tiny-storymade-of-50-first-lines (accessed 5 June 2018).

Schmitz O (dir.) (2000) Hijack Stories. Johannesburg: Xenos Pictures.

Schuster A, Fisher M and Hendrikz A (eds) (2008) Writing the Self: An Anthology of New Writing From Women's Writing Workshops. Cape Town: Women's Writing Workshops.

Shapard R and Thomas J (eds) (1986) Sudden Fiction: American Short-Short Stories. New York: Gibbs Smith.

Shapard R and Thomas J (eds) (1989) Sudden Fiction International: 60 Short-Short Stories. New York: Norton.

Shapard R and Thomas J (eds) (1996) Sudden Fiction (Continued): 60 New Short-Short Stories. New York: Norton.

Shapard R and Thomas J (eds) (2007) New Sudden Fiction: Short-Short Stories from America and Beyond. New York: Norton.

Shapard R, Thomas J and Gonzalez R (eds) (2010) Sudden Fiction Latino: Short-Short Stories from the United States and Latin America. New York: Norton, 2010.

Shields D (2010) Reality Hunger: A Manifesto. New York: Alfred A. Knopf. 
Slovo G (2000) Red Dust. London: Virago Press.

Sole K (2006) Land Dreaming: Prose Poems. Pietermaritzburg: University of KwaZuluNatal Press.

Steinberg J (2015) A Man of Good Hope. London: Jonathan Cape.

Szczurek KM (2009) Not far from the tree. Flash: The International Short-Short Story Magazine 2(1): 15-16.

Szczurek KM (2015) Not far from the tree. In: Merrill C, Thomas J and Shapard R (eds) Flash Fiction International: Very Short Stories From Around the World. New York: Norton, 209-210.

Thomas B (2013) 140 characters in search of a story: Twitterfiction as an emerging narrative form. In: Bell A, Ensslin A and Rustad HK (eds) Analyzing Digital Fiction. New York: Routledge, 94-108.

Thomas J, Thomas D and Hazuka T (eds) (1992) Flash Fiction: 72 Very Short Stories. New York: Norton.

Titlestad M (2010) Afterword: Observations on post-apartheid literature. In: Medalie D The Mistress's Dog: Short Stories 1996-2010. Johannesburg: Picador Africa, 181-191.

Titlestad M (2012) Writing the city after apartheid. In: Attwell D and Attridge D (eds) The Cambridge History of South African Literature. Cambridge: Cambridge University Press, 676-694.

Trimarco P and Hurley U (2008) Less is more: Completing narratives in miniature fiction. 21: Journal of Contemporary and Innovative Fiction 1(1): 82-93.

Turner A (ed.) (1991) The Best of South African Short Stories: Over Seventy Illustrated Stories of Our Land and Its People. Cape Town: The Reader's Digest Association South Africa.

University of Iowa (2007) 2007: Justice - one or many? Available at: https://iwp.uiowa.edu/programs/international-conferences/the-new-symposium/2007 (accessed 5 June 2018).

Van Wyk Smith M (1990) Grounds of Contest: A Survey of South African EnglishLiterature. Kenwyn: Jutalit.

Vladislavić I (1989) Missing Persons. Claremont, Cape Town: David Philip.

Vladislavić I (2006) Portrait with Keys: The City of Johannesburg Unlocked. London: Portobello.

Vladislavić I (2015) 101 Detectives: Stories. Los Angeles and High Wicombe: And Other Stories. 
Vladislavić I (2011) The Loss Library and Other Unfinished Stories. Cape Town: Umuzi.

Walser R (2010) Microscripts (Trans. Bernofsky S). New York: New Directions/Christine Burgin.

Wicomb Z (2001) South African short fiction and orality. In: Bardolph J (ed.) Telling Stories: Postcolonial Short Fiction in English. Amsterdam: Rodopi, 157-170.

Wild P (ed.) (2007) The Flash. London: Social Disease.

Williams M (1999) Hijack City. Cape Town: Oxford University Press Southern Africa.

Williams T (2014) Flash fiction. In: Earnshaw E (ed.) The Handbook of Creative Writing. Edinburgh: Edinburgh University Press, 315-323.

Ziegler A (ed.) (2014) Short: An International Anthology of Five Centuries of Short-Short Stories, Prose Poems, Brief Essays, and Other Short Prose Forms. New York: Norton. 